\title{
ANALISIS PERDAGANGAN BjKU YANG TIDAK SESUAI STANDAR NASIONAL INDONESIA
}

\author{
Gandha Syah Hidayat \\ Universitas Indonesia, Indonesia \\ Email: gandhasyahh@gmail.com
}

\begin{abstract}
ABSTRAK
Tujuan dari penelitian ini adalah menganalisis perdagangan BjKU yang tidak sesuai dengan standar nasional Indonesia. Penelitian menggunakan pendekatan kualitatif dengan metode studi kasus. Teknik pengumpulan data menggunakan observasi, wawancara, studi dokumentasi. Teknik penentuan informan menggunakan purposive. Hasil penelitian menunjukkan bahwa baja keperluan umum yang diperdagangkan di wilayah Indonesia wajib memenuhi Standar Nasional Indonesia (SNI) sebagaimana Peraturan Menteri Perindustrian Nomor : 35/M-IND/PER/5/2014 tentang Pemberlakuan Standar Nasional Indonesia Baja Batangan Keperluan Umum Secara Wajib. Sementara berdasarkan hasil pengujian yang dikeluarkan oleh Balai Besar Bahan dan Barang Teknik (B4T) terhadap besi baja ukuran $6 \mathrm{~mm}$, besi baja ukuran $10 \mathrm{~mm}$ SIS, besi baja ukuran $12 \mathrm{~mm}$ SIS menyatakan BjKU yang diperdagangkan tidak memenuhi standar yang ditetapkan. CV. Karya Virkan telah melanggar aturan terkait perdagangan baja batangan untuk keperluan umum dan dapat dijerat Pasal 113 Undang-undang RI No. 7 tahun 2014 tentang Perdagangan, Pasal 8 Ayat (1) huruf c dan Pasal 62 Ayat (1) dan Undang-undang RI No. 8 tahun 1999 tentang Perlindungan Konsumen.
\end{abstract}

Kata Kunci: Perdagangan BjKU; Standar Nasional Indonesia.

\begin{abstract}
The purpose of this study is to analyze the BjKU trade which is not in accordance with Indonesian national standards. The study uses a qualitative approach with the case study method. Data collection techniques using observation, interviews, study documentation. The technique of determining informants using purposive. The results of the study showed that steel of public use traded in the territory of Indonesia must meet the Indonesian National Standard (SNI) as stipulated in the Minister of Industry Regulation Number: 35 / M-IND / PER / 5/2014 concerning the Imposition of Indonesian National Standard of Steel Bars Obligatory General Purposes. While based on the results of tests issued by the Central Material and Technical Goods (B4T) on $6 \mathrm{~mm}$ steel, $10 \mathrm{~mm}$ SIS steel, $12 \mathrm{~mm}$ SIS steel, the $\mathrm{BjKU}$ traded did not meet the specified standards. CV. Virkan's work has violated regulations related to trade in steel bars for public use and can be charged under Article 113 of the Republic of Indonesia Law No. 7 of 2014 concerning Trade, Article 8 Paragraph (1) letter c and Article 62 Paragraph (1) and RI Law No. 8 of 1999 concerning Consumer Protection.
\end{abstract}

Keywords: BjKU Trading; Indonesian National Standard.

\section{PENDAHULUAN}

Saat ini di Indonesia sedang gencar pembangunan infrastruktur oleh pemerintah yang salah satunya berdampak dengan meningkatnya kebutuhan besi baja nasional. Konsumsi baja suatu negara merupakan salah satu indikator kemajuan negara. Berdasarkan Peraturan Presiden Republik Indonesia Nomor 28 Tahun 2008 Tentang Kebijakan Industri Nasional, maka sektor industri baja dimasukkan ke dalam kelompok industri prioritas bagi basis industri manufaktur. Tambunan (2006) menuliskan bahwa proses industrialisasi utamanya didorong oleh industri baja. Negara-negara industri maju seperti yang kita kenal saat ini semuanya memiliki industri baja yang memadai dan besar.

Berdasarkan data The South East Asia Iron and Steel Institute (SEAISI) pada tahun 2018, jumlah importasi baja 
di Indonesia mencapai 7,6 juta ton dan di semester I 2019 masih terus mengalami peningkatan. Bahkan komoditas besi dan baja tercatat sebagai komoditi impor terbesar ke-3, yaitu sebesar 6,45 persen dari total importasi dengan nilai 10,25 miliar USD (Badan Pusat Statistik, 2018).

Secara umum dapat dilihat bahwa industri baja sangat diperlukan dalam pengembangan perekonomian suatu negara. Krugman (1994) mengungkapkan bahwa pertumbuhan ekonomi di negara-negara Asia lebih didorong oleh pertumbuhan penggunaan input yang luar biasa, seperti tenaga kerja dan modal (capital) daripada oleh keuntungan (gain) dalam efisiensi. Secara implisit, apabila dikaitkan dengan industri baja di dalam negeri, maka dapat dikatakan bahwa industri ini lebih mengandalkan banyaknya tenaga kerja dan modal dibandingkan dengan teknologi. Sato (2009) menulis bahwa Indonesia belum mempunyai industri baja dengan tanurtanur perapian (blast furnaces) yang besar, seperti yang telah dimiliki oleh Korea Selatan, India, Taiwan, dan RRC (Republik Rakyat China).

Penelitian yang dilakukan oleh Qian dan Duncan (1993) menghasilkan penemuan yang menarik. Berdasarkan penelitian yang dilakukan di Argentina, industri baja domestik lebih mengharapkan proteksi dari pemerintah melalui kuota impor. Penelitian ini, secara eksplisit juga menunjukkan bahwa peranan pemerintah cenderung diharapkan dalam sektor industri baja. Price dan Nance (2009) menuliskan bahwa Indonesia adalah salah satu negara yang menerapkan larangan ekspor baja scrap, selain Argentina, Jamaika, Kenya, dan beberapa negara lainnya. RRC, Rusia, dan Ukraina merupakan negara-negara yang menerapkan pelarangan ekspor baja dalam skala luas. Sebenarnya berdasarkan aturan GATT (General Agreement on Tariffs and Trade), larangan ekspor diperbolehkan untuk bahan mentah yang berasal dari sumber daya alam yang tidak dapat diperbarui. Selain itu, larangan ekspor dapat diterapkan dengan alasan untuk perlindungan lingkungan.

Di Indonesia, pemerintah terlibat terus dalam upaya menciptakan kondisi perdagangan dan pasar besi dan baja dalam negeri yang sehat serta iklim usaha yang tetap kondusif. Berdasarkan hal tersebut, maka pemerintah menerbitkan Peraturan Menteri Perdagangan (Permendag) Nomor 08 Tahun 2009 Tentang Ketentuan Impor Besi atau Baja yang kemudian diperbarui dengan Permendag Nomor 21 Tahun 2009 Tentang Perubahan Atas Peraturan Menteri Perdagangan Nomor 08 Tahun 2009 Tentang Ketentuan Impor Besi Atau Baja dan regulasi yang terbaru diperbaharui dengan menerbitkan Peraturan Menteri Perdagangan (Permendag) Nomor 110 Tahun 2018 tentang Ketentuan Impor Besi atau Baja.

Menurut data International Trade Administration (ITA), impor produk baja ke Indonesia sudah meningkat 102\% sepanjang 2009 hingga 2017. Pada 2017, impor baja Indonesia bahkan sudah mencapai 11 juta ton setahun. Data dari Kementerian Perindustrian menunjukkan, kebutuhan konsumsi baja nasional per 2018 lalu mencapai 14 juta ton per tahun, sedangkan produksi baja mentah dalam negeri mencapai 4,8 juta ton pada 2015 , dan turun menjadi 4,7 juta ton pada 2016, kemudian kembali naik mencapai 5,1 juta ton pada 2017. Serbuan baja ini berpengaruh terhadap neraca perdagangan nasional. Produk baja tercatat menjadi 1 dari 3 produk yang dianggap paling berperan membuat nilai impor RI meroket dan berimbas terhadap tekornya neraca dagang RI. Dari data BPS tampak pada 2018, neraca perdagangan tercatat defisit sampai 8,57 miliar dolar AS. (https://tirto. $\mathrm{id} / \mathrm{deN7})$.

Baja batangan keperluan umum (BjKU) menurut Pasal 1 ayat (1) "Peraturan 
Menteri Perindustrian Republik Indonesia Nomor 18/M-Ind/Per/5/2017 Tentang Lembaga Penilaian Kesesuaian Dalam Rangka Pemberlakuan Dan Pengawasan Standar Nasional Indonesia Baja Batangan Untuk Keperluan Umum Secara Wajib" menyatakan:

Baja Batangan untuk Keperluan
Umum, yang selanjutnya disebut
BjKU, adalah baja bukan
paduan (baja karbon) berbentuk
batang, berpenampang bulat
dengan permukaan polos yang
dihasilkan dari proses canai
panasataucanaipanasulangdan
digunakanbukanuntukkeperluan
konstruksi penulangan beton.

Salah satu perusahaan yang memperdagangkan baja batangan yang tidak berstandar SNI ialah CV. Karya Virkan. Perusahaan ini memperdagangkan baja batangan keperluan umum yang tidak sesuai SNI dengan dalih banyak toko besi dan bangunan lain yang melakukan praktek yang sama karena baja batangan yang sesuai dengan SNI memiliki harga tinggi. Jadi mereka lebih cenderung memilih yang tidak SNI dengan alasan memiliki harga yang lebih murah untuk dapat bersaing.

CV. Karya Virkan telah melakukan perdagangan yang tidak fair kepada konsumen yang tidak mengetahui antara BjKU yang berstandar SNI dan tidak memiliki standar SNI. BjKU yang tidak meiliki standar SNI yang tidak melalui tahap pengujian diperdagangkan dengan alasan agar harga bersaing padahal itu sangat membahayakan konsumen karena faktor ketahanan dan kekuatannya yang dianggap kurang. Oleh sebabnya standar SNI wajib dalam BjKU karena keselamatan menjadi faktor utama yang diperhatikan dibandingkan dengan keuntungan.

Oleh karena itu, CV. Karya Virkan diduga melanggar Pasal 113 Undang-undang RI No. 7 tahun 2014 tentang Perdagangan,
Pasal 62 Ayat (1):

Pelaku Usaha yang memperdagangkan Barang di dalam negeri yang tidak memenuhi SNI yang telah diberlakukan secara wajib atau persyaratan teknis yang telah diberlakukan secara wajib sebagaimana dimaksud dalam Pasal 57 ayat (2) dipidana dengan pidana penjara paling lama 5 (lima) tahun dan / atau pidana denda paling banyak Rp5.000.000.000,00 (lima miliar rupiah).

Selanjutnya menurut Pasal 62 ayat (2) Undang-undang RI No. 8 tahun 1999 tentang Perlindungan Konsumen:

Pelaku usaha yang melanggar ketentuan sebagaimana dimaksud dalam Pasal 8, Pasal 9, Pasal 10, Pasal 13 ayat (2), Pasal 15, Pasal 17 ayat (1) huruf a, huruf b, huruf c, huruf e, ayat (2), dan Pasal 18 dipidana dengan pidana penjara paling lama 5 (lima) tahun atau pidana denda paling banyak Rp.2.000.000.000,00 (dua miliar rupiah).

Berdasarkan latar belakang di atas, peneliti merasa tertarik untuk mengambil judul "Perdagangan BjKU Ilegal : Studi Kasus Perdagangan BjKU yang Tidak Sesuai SNI oleh CV Karya Virkan". Penelitian ini memfokuskan kepada mengapa CV Karya Virkan melakukan pelanggaran perdagangan BjKU yang tidak sesuai SNI, bagaimana penegakan hukum perlindungan konsumen, dan bagaimana kendala dan upaya penegakan hukum perlindungan konsumen perdagangan BjKU oleh CV Karya Virkan.

Penelitian ini dianggap penting karena banyak pelaku usaha yang memperdagangkan baja batangan untuk keperluan umum (BjKU) yang tidak sesuai dengan SNI, 
serta masyarakat membutuhkan informasi untuk mengetahui bagaimana pentingnya agar menggunakan baja batangan yang berstandar SNI agar faktor keselamatan dapat tercapai.

\section{METODE}

Pendekatan yang digunakan dalam penelitian ini adalah pendekatan kualitatif. MenurutBogdan dan Tylor(dalam Moleong, 2004) mendefinisikan pendekatan kualitatif sebagai berikut "metode kualitatif sebagai prosedur penelitian yang menghasilkan data deskriptif berupa kata-kata tertulis atau lisan dari orang-orang dan perilaku yang diamati”. Penelitian ini dilakukan dengan cara penelitian hukum normatif atau yuridis normatif yaitu dengan melakukan kajian terhadap norma hukum dan perundangundangan lainnya yang berkaitan dengan permasalahan yang dibahas atau analisis approach (Ibrahim, 2005). Menurut Wignosoebroto (dalam Ali, 2011) penelitian hukum adalah seluruh upaya untuk mencari dan menemukan jawaban yang benar (right answer) dan/atau jawaban yang tidak sekali-kali keliru (true answer) mengenai suatu permasalahan, untuk menjawab segala macam permasalahan hukum diperlukan hasil penelitian yang cermat dan sahih untuk menjelaskan dan menjawab permasalahan yang ada.

Selanjutnya Creswell (2008, hlm. 50) mendefinisikan:

"Qualitative research is an inquiry process of understanding based on distinct methodological traditions of inquiry that explore a social or human problem. The researcher builds a complex, holistic picture, analyzes words, reports detailed views of informants, and conducts the study in a natural setting"

Berkaitan dengan studi kasus, menurut Gay dkk (2009, hlm. 426) mengemukakan: "case study research is a qualitative approach to studying a phenomenon, focused on a unit af study or a bounded system, not a methodological choice, but a choice of what to study, an allencompassing research method."

Teknik pengumpulan data dalam penelitian ini melalui observasi, wawancara, dan studi dokumentasi. "Analisis data dalam penelitian kualitatif dilakukan pada saat pengumpulan data berlangsung dan setelah selesai pengumpulan data dalam periode tertentu. Miles dan Huberman (dalam" Sugiyono, 2011) mengemukakan bahwa aktivitas dalam analisis data kualitatif di lakukan secara interaktif dan berlangsung secara terus menerus sampai tuntas sehingga datanya jenuh. Aktivitas dalam analisis data" pada penelitian ini, diantaranya reduksi data (data reduction), penyajian data (data display), dan kesimpulan atau verifikasi (conclusion drawing).

Berdasarkan penjelasan di atas, maka penelitian ini akan mengambil data dari berbagai sumber, yakni: (1) Penyidik Subdit Industri dan Perdagangan (Indag) Ditreskrimsus Polda Jabar; (2) Karyawan CV Karya Virkan; (3) Pemilik CV Karya Virkan; (4) Konsumen CV Karya Virkan; (5) Pemilik Toko Besi/ Bangunan Lain; (6) Pegawai Laboratorium Balai Besar Barang \& Bahan Teknik (B4T) Provinsi Jabar; (7) Ahli Perlindungan Konsumen dari Disperindag Prov Jabar; (8) Ahli SNI dari Badan Standarisasi Nasional (BSN).

HASIL DAN PEMBAHASAN

Perdagangan Baja Batangan Untuk Keperluan Umum (BjKU) yang tidak sesuai SNI oleh CV. Karya Virkan

Baja batangan keperluan umum (BjKU) menurut Pasal 1 ayat (1) Peraturan Menteri Perindustrian Republik Indonesia Nomor 18/M-Ind/Per/5/2017 Tentang Lembaga Penilaian Kesesuaian Dalam 
Rangka Pemberlakuan Dan Pengawasan Standar Nasional Indonesia Baja Batangan Untuk Keperluan Umum Secara Wajib menyatakan:

Baja Batangan untuk Keperluan
Umum, yang selanjutnya disebut
BjKU, adalah baja bukan paduan
(baja karbon) berbentuk batang,
berpenampang bulat dengan
permukaan polos yang dihasilkan
dari proses canai panas atau
canai panas ulang dan digunakan
bukan untuk keperluan konstruksi
penulangan beton.

Lebih lanjut ukuran besi baja merek SIS ukuran $12 \mathrm{~mm}, 10 \mathrm{~mm}$ dan besi baja ukuran $6 \mathrm{~mm}$ yang diperdagangkan kepada konsumen dengan ukuran sebagaimana yang tercantum seharusnya besi baja tersebut atau ukuran yang sebenarnya adapun ukuran yang sebenarnya dari besi baja tersebut yaitu: (1) Besi baja merek SIS ukuran $12 \mathrm{~mm}$ ukuran diameternya yaitu 10,6 mm; (2) Besi baja merek SIS ukuran $10 \mathrm{~mm}$ ukuran diameternya yaitu 8,6 ; (3) Besi baja ukuran $6 \mathrm{~mm}$ ukuran diameternya yaitu $5 \mathrm{~mm}$.

Salah satu perusahaan yang memperdagangkan baja batangan yang tidak berstandar SNI ialah CV. Karya Virkan. Perusahaan ini memperdagangkan baja batangan keperluan umum yang tidak sesuai SNI dengan dalih banyak toko besi dan bangunan lain yang melakukan praktek yang sama karena baja batangan yang sesuai dengan SNI memiliki harga tinggi. Jadi mereka lebih cenderung memilih yang tidak SNI dengan alasan memiliki harga yang lebih murah untuk dapat bersaing.

Berdasarkan keterangan Ahli dari Dinas Perindustrian dan Perdagangan Provinsi Jawa Barat menerangkan bahwa baja keperluan umum yang diperdagangkan di wilayah Indonesia wajib memenuhi Standar Nasional Indonesia (SNI) sebagaimana Peraturan Menteri Perindustrian Nomor:
35/M-IND/PER/5/2014

tentang

Pemberlakuan Standar Nasional Indonesia Baja Batangan Keperluan Umum Secara Wajib. Sementara berdasarkan hasil pengujian yang dikeluarkan oleh Balai Besar Bahan dan Barang Teknik (B4T) terhadap besi baja ukuran $6 \mathrm{~mm}$, besi baja ukuran $10 \mathrm{~mm}$ SIS, besi baja ukuran $12 \mathrm{~mm}$ SIS diketahui sebagai berikut: (1) Baja batangan keperluan umum merek SIS ukuran $10 \mathrm{~mm}$ hasil uji diameternya $8,14 \mathrm{~mm}$ sedangkan batas toleransi untuk ukuran tersebut adalah $0,4 \mathrm{~mm}$ dan untuk berat hasil uji diketahui 0,403 sedangkan berat nominal untuk ukuran $10 \mathrm{~mm}$ adalah $0,746 \mathrm{~kg} / \mathrm{mm}$ dengan toleransi kesalahan sebesar $6 \%=0,04476$, dengan kesimpulan besi tersebut tidak memenuhi Standar Nasional Indonesia (SNI); (2) Baja batangan keperluan umum merek SIS ukuran $12 \mathrm{~mm}$ hasil uji diameternya 9,94 mm sedangkan batas toleransi untuk ukuran tersebut adalah $0,4 \mathrm{~mm}$ dan untuk berat hasil uji diketahui 0,588 sedangkan berat nominal untuk ukuran $12 \mathrm{~mm}$ adalah $0,888 \mathrm{~kg} / \mathrm{mm}$ dengan toleransi kesalahan sebesar $6 \%=0,05328$, dengan kesimpulan besi tersebut tidak memenuhi Standar Nasional Indonesia (SNI); (3) Besi baja ukuran $6 \mathrm{~mm}$ hasil uji diameternya 4,45 mm sedangkan batas toleransi untuk ukuran tersebut adalah $0,2 \mathrm{~mm}$ dan untuk berat hasil uji diketahui 0,117 sedangkan berat nominal untuk ukuran $6 \mathrm{~mm}$ adalah 0,222 $\mathrm{kg} / \mathrm{mm}$ dengan toleransi kesalahan sebesar $7 \%=0,01554$ dan tidak berlogo SNI, dengan kesimpulan besi tersebut tidak memenuhi Standar Nasional Indonesia (SNI).

Berdasarkan hasil wawancara terhadap Pemilik CV Karya Virkan (HW), selama Ia melakukan perdagangan di bidang usahanya lebih dari 10 tahun sejak tahun 2008 tidak pernah ada masalah ataupun komplain dari barang ataupun konsumen. Selama berdagang baja batangan untuk keperluan umum (BjKU) Ia merasa 
telah sesuai dan memenuhi kriteria yang ditetapkan seharusnya. Hal itu terbukti dari tidak adanya keluhan dari konsumen yang membeli barang darinya karena sesuai dengan yang diinginkan oleh konsumen.

Lebih lanjut HW menuturkan bahwa Ia baru satu bulan memperdagangkan BjKU yang tidak sesuai dengan SNI dan itu pun belum sempat diperjualbelikan di pasaran. Ia mengaku memperjualbelikan karena tidak mengetahui BjKU yang boleh dan tidak boleh diperjualbelikan karena selama Ia berdagang tidak pernah mendapat sosialisasi atau penyuluhan dari pemerintah terkait hal yang dituduhkan kepadanya. Ia baru mengetahui setelah terkena kasus yang menjeratnya saat ini.

Namun di sisi lain Ia mengakui bahwa karena ketidaktahuan atau kelalaiannya dalam berdagang dan kurangnya pengetahuannya terkait hal tersebut yang menyebabkan Ia terkena masalah. Ia mendapatkan BjKU dari marketing perusahaan yang berada di Jakarta dan tidak mengetahui bagaimana peredaran BjKU saat ini di Indonesia. Terkait dengan kualitas BjKU yang Ia perdagangkan, tidak terlalu mengetahui perbedaan kualitas antara BjKU yang sesuai SNI dan tidak sesuai SNI, namun yang jadi pertimbangannya dan pertimbangan konsumen adalah masalah harga karena BjKU yang tidak sesuai SNI lebih murah dan akan laku di pasaran.

Penuturan HW bahwa pemerintah dalam hal ini instansi terkait harus pro aktif dan terjun ke lapangan untuk memberikan penyuluhan kepada pengusaha dan masyarakat tentang standar SNI yang ditetapkan oleh pemerintah karena yang Ia rasakan tidak ada sosialisasi yang dilakukan. Ia berpendapat jangan sampai pengusaha atau pedagang, konsumen, dan masyarakat dirugikan dengan kelalaian dari pemerintah atau instansi terkait.

Berdasarkkan pendapat di atas maka apapun alasannya seperti yang diungkap di atas karena kurangnya pengetahuan, yang bersangkutan telah melanggar hukum melakukan perbuatan perdagangan $\mathrm{BjKU}$ yang tidak standar SNI dan pelaku harus mempertanggungjawabkannya di muka hukum. Perbuatan tersebut membahayakan keselamtan dan keamanan konsumen sebagai pengguna dan meresahkan masyarakat yang tidak mengetahui tentang standar SNI yang diberlakukan.

\section{Penegakan Hukum Perlindungan Konsumen Perdagangan Baja Batangan untuk Keperluan Umum (BjKU) yang tidak sesuai SNI oleh CV. Karya Virkan}

Kejahatan merupakan bagian kehidupan masyarakat dan merupakan peristiwa sehari-hari. Jauh sebelumnya, seorang filsuf bernama Cicero mengatakan "Ubi Societas, Ibi Ius, Ibi Crimen (ada Masyarakat, ada Hukum, dan ada Kejahatan). Menurut Rukmini (2014: 4) hal ini terjadi karena:"

"Masyarakat saling menilai, menjalin interaksi dan komunikasi, tidak jarang timbul konflik atau pertikaian. Kejahatan tetap merupakan misteri, sulit ditembus, tetapi sekaligus fenomena yang tidak pernah habis dan selalu menarik untuk dikaji. Banyak orang sepakat bahwa meskipun kejahatan bukan sesuatu yang dapat diberantas atau dihapuskan, tetapi perlu ditanggulangi dan disikapi dengan serius."

Masyarakat dan ketertiban yang diciptakan oleh hukum menurut Rahardjo (2006) merupakan:

"Dua hal yang berhubungan sangat erat, bahkan bisa juga dikatakan sebagai dua sisi dari suatu mata uang. Susah untuk mengatakan adanya masyarakat tanpa ada suatu ketertiban, bagaimana pun kualitasnya. Kendati demikian segera perlu ditambahkan disini, 
bahwa yang disebut dengan ketertiban itu tidak didukung oleh suatu lembaga yang monolitik. Ketertiban dalam masyarakat diciptakan bersamasama oleh berbagai lembaga secara bersama-sama, seperti hukum dan tradisi. Oleh karena itu dalam masyarakat juga dijumpai berbagai macam norma yang masing-masing memberikan sahamnya dalam menciptakan ketertiban itu. Sekalipun hukum bukanlah satusatunya sarana menciptakan ketertiban dalam masyarakat".

Resolusi Perserikatan Bangsabangsa Nomor 39/248 Tahun 1985 tentang Perlindungan Konsumen (Guidelines for Consumer Protection), juga merumuskan berbagai kepentingan konsumen yang perlu dilindungi, yang meliputi: (1) Perlindungan konsumen dari bahaya-bahaya terhadap kesehatan dan keamanannya; (2) Promosi dan perlindungan kepentingan ekonomi sosial konsumen; (3) Tersedianya informasi yang memadai bagi konsumen untuk memberikan kemampuan mereka melakukan pilihan yang tepat sesuai kehendak dan kebutuhan pribadi; (4) Pendidikan konsumen; (5) Tersedianya upaya ganti rugi yang efektif; (6) Kebebasan untuk membentuk organisasi konsumen atau organisasi lainnya yang relevan dan memberikan kesempatan kepada organisasi tersebut untuk menyuarakan pendapatnya dalam proses pengambilan keputusan yang menyangkut kepentingan mereka (Gunawan Widjaja \& Ahmad Yani, 2001).

Menurut Rahardjo (1987) "penegakan hukum adalah suatu usaha untuk mewujudkan ide-ide tentang keadilankeadilan, kepastian hukum dan kemanfaatan sosial menjadi kenyataan. Sementara menurut Peter Mahmud Marzuki (2012) penegakan hukum pidana adalah suatu usaha untuk mewujudkan ide-ide tentang kedilan dalam hukum pidana dalam kepastian hukum dan kemanfaatan sosial menjadi kenyataan hukum dalam kepastian hukum dan kemanfaatan sosial menjadi kenyataan hukum dalam setiap hubungan hukum.

"Penegakan hukum adalah proses dilakukannya upaya untuk tegaknya atau berfungsinya norma-norma hukum secara nyata sebagai pedoman prilaku dalam lalu lintas atau hubunganhubungan hukum dalam kehidupan bermasyarakat dan bernegara. Ditinjau dari sudut subyeknya, penegakan hukum itu dapat dilakukan oleh subyekyang luas dan dapat pula diartikan sebagai upaya penegakan hukum itu melibatkan semua subyek."

Menurut Hamzah (2005), istilah penegakan hukum sering disalah artikan seakan akan hanya bergerak di bidang hukum pidana atau di bidang represif. Istilah penegakan hukum disini meliputi baik yang represif maupun yang preventif. Jadi kurang lebih maknanya sama dengan istilah Belanda rechtshanhaving. Berbeda dengan istilah law enforcement, yang sekarang diberi makna represif, sedangkan yang preventif berupa pemberian informasi, persuasif, dan petunjuk disebut law compliance, yang berarti pemenuhan dan penataan hukum. Oleh karena itu lebih tepat jika dipakai istilah penanganan hukum atau pengendalian hukum.

Menurut penyidik Subdit Indag Ditreskrimsus Polda Jabar (AH) memang saat ini perdagangan $\mathrm{BjKU}$ sedang marak dan Ia mengetahui tentang peredarannya khususnya di Jawa Barat. Beredarnya BjKU yang tidak sesuai SNI perlau dilakukan penegakan hukum yang tegas kepada para pelaku usaha yang memperdagangkan BjKU yang tidak sesuai SNI yang telah 
diberlakukan seacra wajib karena telah melanggar peraturan perundang-undangan yang berlaku.

Menurutnya saat ini peredaran $\mathrm{BjKU}$ lebih banyak di pasaran beredar dibanding dengan BjKU yang sesuai dengan SNI. Hingga saat ini menurut pengakuan AA sudah ada 16 kasus yang diproses terkait pelaku usaha yang memperdagangkan BjKU yang tidak sesuai dengan SNI. Pasal yang dilanggar bagi pelaku usaha yang memperdagangkan BjKU tidak sesuai standar SNI yaitu pasal 113 UU No 7 tahun 2014 tentang Perdagangan atau pasal 62 ayat (1) jo. Pasal 8 ayat (1) huruf c UU No 8 tahun 1999 tentang Perlindungan Konsumen. Hal ini terjadi karena kurangnya kesadaran dari pengusaha untuk mengikuti aturan memperdagangkan $\mathrm{BjKU}$ yang sesuai dengan standar SNI.

Pihak kepolisian terus melakukan penyelidikan terhadap toko bangunan atau distributor yang memperdagangkan BjKU tidaksesuaistandarSNI,melakukanpengujian terhadap BjKU yang diperdagangkan, dan apabila terbukti memperdagangkan BjKU yang tidak sesuai SNI maka akan dilanjutkan ke tingkat penyidikan lebih lanjut. Berkaitan dengan aturan perdagangan BjKU yang sesuai dan tidak sesuai standar SNI, pihak kepolisian tidak melakukan osialisasi karena bukan kewenangannya, menurutnya yang lebih berwenang melakukan sosialisasi ialah pihak Dinas Perdagangan dan dari Badan Standarisasi Nasional (BSN). Sanksi bagi pelaku usaha atau penjual yang memperdagangkan BjKU yang tidak sesuai standar SNI ialah hukuman penjara selama 5 tahun sesuai dengan pasal 113 UU No 7 tahun 2014 tentang Perdagangan atau pasal 62 ayat (1) jo. Pasal 8 ayat (1) huruf c UU No 8 tahun 1999 tentang Perlindungan Konsumen.

Sementara itu berdasarkan hasil wawancara terhadap penyidik lain di Subdit Indag Ditreskrimsus Polda jabar (TH) bahwa Ia mengetahui terhadap praktik perdagangan BjKU ilegal. Menurutnya perdagangan BjKU ilegal akan merugikan masyarakat selaku konsumen karena tidak sesuai ukuran yang sebenarnya dan dapat membahayakan keselamatan. Peredaran BjKU ilegal lebih banyak dibanding yang sesuai dengan SNI karena harganya yang lebih murah. Besarnya permintaan pasar karena kurangnya pengetahuan dan kesadaran masyarakat membuat BjKU yang tidak standar SNI marak di pasar.

Peran utama kepolisian dalam hal ini ialah melakukan penegakan hukum terhadap para pelanggar pelaku usaha yang melakukan perdagangan BjKU yang tidak standar SNI dan melakukan pengecekan kepada pelaku usaha di wilayah hukum Polda Jawa Barat untuk emmastikan bahwa yang diperdagangkan ialah BjKU yang berstandar SNI. Sanksi bagi pelaku usaha atau penjual yang memperdagangkan BjKU yang tidak sesuai standar SNI ialah hukuman penjara selama 5 tahun sesuai dengan pasal 113 UU No 7 tahun 2014 tentang Perdagangan atau pasal 62 ayat (1) jo. Pasal 8 ayat (1) huruf c UU No 8 tahun 1999 tentang Perlindungan Konsumen.

Berdasarkan hasil wawancara terhadap Penyuluh Madya Disperindag Provinsi Jawa Barat (ESH) bahwa BjKU merupakan SNI wajib No. 76142010, batas toleransinya diatur mulai dari besi 5 hingga besi 19, BjKU tersebut dijual oleh distributor dan pedagang pengecer dengan label SNI merk yang berbeda-beda, namun untuk mengukur sesuai atau tidaknya harus diuji di laboratorium. Biasanya harga yang murah itu perlu diragukan, karena contohnya merk Krakatau Steel (KS) itu kan mahal nah umumnya itu telah sesuai SNI.

Menurut ESH ada beberapa pelaku usaha yang telah diberi sanksi UU Perdagangan dan UU Perlindungan Konsumen. Disperindag juga telah melakukan peringatan kepada pelaku usaha yang nakal menjual BjKU tidak 
sesuai standar SNI. Selaku petugas pengawas, Ia melakukan pengawasan kepada distributor dan pedagang secara berkala dan meminta sertifikat SPPT SNI setiap merk BjKU kepada suplayer. Pihak Disperindag juga mengaku telah melakukan sosialisasi bekerjasama dengan Kementerian Perdagangan dan Kementerian Perindustrian.

Lebih lanjut menurut konsumen (NA), berdasarkan pengalamannya Ia pernah membeli besi full ukuran $8 \mathrm{Rp}$. 38.000, ukuran 10 Rp. 58.000, dan ukuran 12 Rp. 103.000. menurutnya meskipun lebih mahal Ia memilih besi full karena lebih bagus kualitasnya. Ia memahami bahwa tujuan SNI untuk keselamatan dan keamanan. Peredaran BjKU harus dipantau agar tidak ada lagi barang yang tidak berstandar SNI beredar dan merugikan juga membahayakan konsumen.

Senada dengan pernyataan di atas, (DI) selaku pelaksana proyek pun menyadari bahwa peredaran BjKU yang tidak SNI cukup marak dan harus dibatasi bila perlu ditiadakan. Namun Ia tidak menyalahkan penjual asalkan terbuka jujur kepada konsumen untuk memberikan pilihan akan membeli besi baja SNI ataupun tidak SNI. Tetapi bila penjual tidak menjelaskan kepada konsumen maka itu harus ditindak menurutnya karena merugikan konsumen.

Temuan Indag Jawa Barat "pihaknya menemukan sedikitnya lima merek dagang besi beton yang terindikasi mengelabui konsumen. Ia mencontohkan besi beton bermerek dagang PCI yang dijual di salah satu toko di Desa Sekarwangi, Kecamatan Soreang. Merek dagang tersebut mendistribusikan besi beton dalam tiga ukuran diameter yaitu 8,10 dan 12 milimeter yang sebenarnya mencantumkan label SNI di toko tersebut. Namun ukuran riilnya hanya 7,0 milimeter untuk besi 8; 8,8 milimeter untuk besi 10, dan 10,6 milimeter untuk besi 12."
Hal serupa ditemukan pada merek dagang MSI di Kecamatan Cangkuang yang hanya berukuran 7,46 milimeter untuk besi 8 dan 9,22 milimeter untuk besi 10. Selain itu ada juga besi 10 merek dagang DAS yang hanya berukuran riil 8,24 milimeter serta besi 12 merek SSTY berukuran 11,5 milimeter dan besi 8 merek JSM berukuran 7,03 milimeter. Standar toleransi yang diberikan hanya sekitar 0,4 milimeter. Jadi seharusnya kalau besi 12 ukuran riilnya minimal 11,6 milimeter. Begitu juga untuk besi 10 minimal 9,6 milimeter dan besi 8 minimal 7,6 milimeter.

"Pihaknya akan melaporkan temuan tersebut ke pemerintah pusat untuk ditindaklanjuti ke produsen atau distributornya. Sementara para penjual dibina untuk tidak lagi menerima besi beton tak sesuai standar dari distributor dan untuk barang yang sudah ada, mereka ditekankan untuk tidak menjualnya ke konsumen dan justru mengembalikannya ke distributor. Sementara itu penjual besi beton di Soreang, (DG) mengakui dirinya teledor karena tidak memeriksa kembali barang yang dikirim distributor. Namun ia sama sekali tidak mengetahui bahwa barang tersebut ternyata tidak sesuai ukuran semestinya.

Hal serupa diungkapkan oleh pedagang Kecamatan Cangkuang, (AC ) yang mengaku juga pernah didatangi aparat kepolisian sebelum didatangi tim dari Indag Jabar. Gara-gara besi beton yang tidak sesuai standar SNI, tokonya pernah ditutup sampai sekitar sebulan untuk kepentingan penyelidikan. Ia mengaku hal itu cukup merugikan karena dalam sebulan tersebut ia tak mendapatkan penghasilan sama sekali. Bahkan setelah tokonya kembali buka pun, ia kehilangan banyak langganan yang lari ke toko lain. Padahal sebenarnya barang seperti itu juga dijual di toko lain, karena dulu Ia jual yang sesuai standar harganya mahal jadi konsumen lari ke toko lain. Kalau memang aturan harus ditegakan maka akan ikuti, tetapi harus 
diterapkan untuk semua. Jangan sampai ada satu toko pun yang menjual besi beton yang tak sesuai standar.

Upaya penegakan hukum di bidang penegakan hukum perlindungan konsumen terus ditegakkan. Kepolisian, Kementerian Perdagangan, serta para stakeholder lainnya terus berupaya untuk mengawasi barang yang beredar yang tak sesuai standar. Apabila ditemukan pelanggaran perdagangan khususnya baja batangan untuk keperluan umum yang tidak sesuai dengan SNI, maka akan dihadapkan dengan hukum pidana dengan pasal-pasal yang menjerat diantaranya: Pasal 113 Undang-undang RI No. 7 tahun 2014 tentang Perdagangan, Pasal 62 Ayat (1):

Pelaku Usaha yang
memperdagangkan Barang
di dalam negeri yang tidak
memenuhi SNI yang telah
diberlakukan secarawajibatau
persyaratan teknis yang telah
diberlakukan secara wajib
sebagaimana dimaksud dalam
Pasal 57 ayat (2) dipidana
dengan pidana penjara paling
lama 5 (lima) tahun dan / atau
pidana denda paling banyak
Rp5.000.000.000,00 (lima
miliar rupiah).

Pasal 62 ayat (1) Undang-undang RI No. 8 tahun 1999 tentang Perlindungan Konsumen:

Pelaku usaha yang melanggar ketentuan sebagaimana dimaksud dalam Pasal 8, Pasal 9, Pasal 10, Pasal 13 ayat (2), Pasal 15, Pasal 17 ayat (1) huruf a, huruf b, huruf c, huruf e, ayat (2), dan Pasal 18 dipidana dengan pidana penjara paling lama 5 (lima) tahun atau pidana denda paling banyak Rp.2.000.000.000,00 (dua miliar rupiah).
Kendala dan Solusi Penegakan Hukum Perlindungan Konsumen Perdagangan Baja Batangan untuk Keperluan Umum (BjKU) yang tidak sesuai SNI oleh CV. Karya Virkan

Berdasarkan hasil wawancara terhadap $\mathrm{AH}$, kendala peredaran dan perdagangan BjKU yang tidak sesuai SNI selama ini ditemukan dengan menggunakan sales secara putus, sehingga tidak dapat dikembangkan langsung ke pihak produsen atau pabrik yang memproduksi BjKU yang tidak sesuai SNI.

Menurut AH solusi menyikapi peredaran BjKU ilegal ialah: (a) Memberikan sosialisasi kepada para pelaku usaha yang memperdagangkan BjKU dan masyarakat selaku konsumen pengguna $\mathrm{BjKU}$ terkait peraturan tentang BjKU yang telah diwajibkan oleh pemerintah untuk memenuhi standar SNI; (b) Dilakukan pengawasan oleh isntansi terkait secara berkala terhadap produsen BjKU, distributor yang memperdagangkan BjKU; dan (c) Menutup produsen yang terbukti memproduksi BjKU yang tidak sesuai standar SNI.

Sementara itu menurut $\mathrm{TH}$ kendala yang dihadapi menyikapi perdagangan BjKU ilegal adalah kurangnya peran aktif dari dinas terkait yakni Dinas Perdagangan dan Dinas Perindustrian dalam melakukan pengawasan perdagangan BjKU. Menurutnya faktor pengawasan menjadi hal penting untuk melakukan pencegahan peredaran BjKU yang tidak standar SNI agar tidak sampai ke distributor dan diperdagangkan ke konsumen. Menurut TH solusi menyikapi peredaran BjKU yang tidak standar SNI adalah pengawasan oleh Dinas terkait bekerjasama dengan pihak kepolisian dan dilakukan hingga tingkat pedagang kecil BjKU.

Berdasarkan wawancara terhadap ESH diperoleh informasi bahwa kendala yang dialami antara lain: (a) Pengecekan ukuran tidak dapat sampai ke pedagang 
bawah karena membutuhkan biaya besar dan waktu yang lama karena sulit untuk mendatangi satu persatu pedagang untuk mengecek ukuran BjKU; (b) Apabila pabrik BjKU yang berada di luar wilayah Jawa Barat perlu diawasi; (c) Pemahaman kepada masyarakat akan pentingnya BjKU SNI yang belum merata; (d) Kesadaran pelaku usaha maupun industri yang melalaikan keselamatan dan kemanan konsumen.

Solusi menangani permasalahan BjKU ilegal perlunya penegakan aturan yang tidak pandang bulu dan pengawasan yang lebih ketat agar BjKU sesuai standar SNI untuk tujuan keamanan dan keselamatan konsumen pengguna.

Berdasarkan hasil wawancara terhadap E dari BSN menyatakan bahwa hambatan yang dialami dalam menyikapi BjKU yang tidak SNI meliputi: (a) Kurangnya mekanisme pengawasan pasar daerah potensial sehingga dimanfaatkan oleh produsen nakal; (b) Integritas dari pelaku usaha yang memasok barang yang tidak SNI; (c) Persaingan harga antara BjKU yang SNI dan tidak SNI yang jauh berbeda; (d) Pengetahuan masyarakat akan pentingnya penggunaan produk yang berstandar SNI.

Lebih lanjut solusi menyikapi BjKU yang tidak SNI meliputi: (a) Mengembangkan program pengawasan pasar yang dikoordinasikan Kementerian Perdagangan dengan Pemerintah Daerah dan penegak hukum; (b) Mengembangkan program pengawasan pra pasar yang dikoordinasikan Kementerian Perdagangan dengan Pemerintah Daerah dan penegak hukum; (c) Sosialisasi pentingnya SNI bagi masyarakat; (d) Melakukan analisis kesenjangan terhadap keberterimaan harga BjKU pada masyarakat, agar dapat diterima dengan baik melakukan uji petik pemenuhan terhadap SNI yang lebih komprehensif.
Berdasarkan hasil wawancara terhadap B4T (AMH) menyatakan kendala belum optimalnya pengawasan, baik terhadap peredaran komoditi BjKU di pasaran maupun pengawasan di area produksi/manufaktur. Kurangnya kesadaran para pelaku usaha untuk memproduksi komoditi BjKU sesuai SNI, keterbatasan ketersediaan infrastruktur pengujian sehingga BjKU beredar apa adanya tanpa melalui proses pengujian \& sertifikasi, dan juga keterbatasan Sumber Daya Manusia (SDM) yang kompeten di bidangnya sehingga komoditi BjKU yang ada tidak sesuai dengan ekspektasi masyarakat.

Solusinya perlu ditingkatkan kembali pengawasan terhadap peredaran BjKU oleh pihak-pihak terkait, memberikan sanksisanksi sesuai peraturan perundangan yang berlaku kepada pelaku usaha yang tidak taat peraturan/regulasi, bila perlu mencabut izin usaha dari pelaku usaha dan distributor, dan perlu disosialisasikan kembali terhadap pelaku usaha, baik besar maupun kecil tentang komoditi BjKU ini yang sudah SNI wajib, yang berarti peredaran komoditi BjKU tidak bisa dipasarkan secara bebas tetapi harus melalui proses sertifikasi dan pengujian.

Sedangkan untuk para Lembaga Sertifikasi Produk (LSPro) perlu menggalakkan kegiatan sertifikasi BjKU yang sudah SNI wajib dan koordinasi dengan pihak-pihak terkait, seperti Kementerian Perdagangan, Kementerian Keuangan (Ditjen Bea dan Cukai), Kepolisian, dan pihakpihak lainnya agar segala bentuk peredaran komoditi BjKU di wilayah Indonesia yang tidak sesuai SNI dan tidak melalui prosedur sertifikasi dan pengujian harus dilarang dan ditarik peredarannya untuk dihanguskan (dihancurkan) dan para pelaku usaha maupun importir diberi sanksi. Hal ini untuk memberikan efek jera terhadap pelaku yang nakal. 


\section{SIMPULAN}

Mengacu pada pembahasan dan hasil penelitian yang dilakukan oleh peneliti terkait dengan Perdagangan BjKU Ilegal : Studi Kasus Perdagangan BjKU yang Tidak Sesuai SNI oleh CV Karya Virkan.

\section{DAFTAR PUSTAKA}

Ali, H. Z. (2011). Metode Penelitian Hukum, Jakarta: Sinar Grafika,

Arief, B. N. (2001). Masalah Penegakan Hukum dan Kebijakan Penanggulangan Kejahatan. Bandung. PT. Citra Aditya Bakti.

Badan Pusat Statistik (BPS). (2018). Statistik Perdagangan Luar Negeri ekspor . Jakarta: Badan Pusat Statistik.

Creswell, J. (2013). Research Design Qualitative, Quantitative, dan Mixed Approaches. California.

Hamzah, A. (2005). Hukum Acara Pidana Indonesia. Jakarta: Sinar Grafika.

Ibrahim, J. (2005). Teory dan Metodologi Penelitian Hukum Normatif. Surabaya: Bayumedia Publishing.

Jannah, Selfie Miftahul. (2019). Baja Impor Rugikan Industri Nasional, Siapa Salah?. (online) https://tirto.id/bajaimpor-rugikan-industri-nasionalsiapa-salah-deN7 diakses 2 mei 2020

Marzuki, P. M. (2009). Penelitian Hukum. Jakarta: Kencana Prenada Media Group.

Moleong, J.X. (2004). Metode Penelitian Kualitatif. Bandung: PT Remaja Rosdakarya.

Rahardjo, S. (2006). Ilmu Hukum. Cetakan keenam. Bandung: Citra Aditya Bakti.

Rukmini, M. (2014). Aspek Hukum Pidana dan Kriminologi. Bandung: Alumni.

Sugiyono. (2012). Metode Penelitian Pendidikan, Pendekatan Kuantittif, Kualitatif, dan R\&D. Bandung: Alfabeta.

Widjaja, G dan Yani, A. (2001). Hukum Tentang Perlindungan Konsumen, Cetakan Kedua. Jakarta: Gramedia
Pustaka Utama.

Krugman, P. (1994). The myth of Asia's miracle. Foreign affairs, 62-78.

Price, A., \& Nance, S. (2009). Export barriers and global trade in raw materials: The steel industry experience. report to the Raw Materials Committee of the OECD. Washington, DC: Wiley Rein LLP.

Qian, Y., \& Duncan, R. C. (1993). Privatization, concentration, and pressure for protection: a steel sector study (No. 1112). The World Bank.

Rahardjo,S.(1982).KeadaandanPermasalahan dalam Penegakan Hukum Dewasa ini. Bandung: Bina cipta.

Sato, H. (2009). The iron and steel industry in Asia: Development and restructuring (No. 210). Institute of Developing Economies, Japan External Trade Organization (JETRO).

Tambunan, T., \& Indonesia-JETRO, K. (2006). The growth of national steel industry. Kadin Indonesia-JETRO.

Peraturan Menteri Perdagangan Nomor 110 Tahun 2018 tentang Ketentuan Impor Besi atau Baja.

Peraturan Pemerintah Nomor 102 tahun 2000 tentang Standarisasi Nasional

Peraturan Presiden Republik Indonesia Nomor 28 Tahun 2008 Tentang Kebijakan Industri Nasional

Peraturan Menteri Perindustrian Republik Indonesia Nomor 18/M-Ind/Per/5/2017 Tentang Lembaga Penilaian Kesesuaian Dalam Rangka Pemberlakuan Dan Pengawasan Standar Nasional Indonesia Baja Batangan Untuk Keperluan Umum Secara Wajib

Undang-undang RI No. 7 tahun 2014 tentang Perdagangan

Undang-undang RI No. 8 tahun 1999 tentang Perlindungan Konsumen. 